\title{
PRELIMINARY STUDY OF THE EFFECT OF CHEMICAL AND ORGANIC FERTILIZERS ON A SEMI-NATURAL GRASSLAND IN VLĂHIȚA, HARGHITA MOUNTAINS, ROMANIA
}

\author{
Katalin MOLNÁR ${ }^{1}$, Imre-István NYÁRÁDI ${ }^{1}$, Béla BÍRÓ-JANKA ${ }^{1}$, István SIMÓ ${ }^{1}$, János \\ BÁLINT $^{1}$, Erzsébet DOMOKOS $^{1 *}$ \\ ${ }^{1}$ Department of Horticulture, Faculty of Technical and Human Sciences, Târgu-Mureş, Sapientia Hungarian \\ University of Transylvania, Cluj-Napoca, Romania
}

*Correspondence:

Erzsébet DOMOKOS

domokos.erzsebet@ms.sapientia.ro

Received: 14 November 2020; Accepted: 15 December 2020; Published: 30 December 2020

\begin{abstract}
The aim of the research was to examine the effect of different fertilizers on the floristic composition and biomass yield of the semi-natural grassland used as hayfield near Vlăhița locality (Harghita County, Romania) in order to improve its management. In the same time the qualitative structure of the studied grassland was evaluated after the first application of the fertilizers. The vegetation survey was made before mowing, and a total of 84 plant taxa were identified. The studied plant community belongs to the association Festuco-Agrostetum capillaris Horv. 1951. From the 31 fodder species, 13 had very good or good nutritional value. The qualitative structure analysis indicates that the vegetation has developed under moderate anthropogenic pressure. Beside the Euro-Asian elements the Circumpolar and the Cosmopolite elements were well represented. Many species with high tolerance for temperature, soil $\mathrm{pH}$, and soil mineral nitrogen content were registered. After the first application of fertilizers in all treated plots the biodiversity increased compared to the control plot. Fertilized plots also had a significantly higher biomass yield than the control plot. All fertilizers reduced the proportion of the species with good nutritional value from the Poaceae family. Organic fertilizer affected positively the proportion of other plant families than Poaceae and Fabaceae. Long-term experiments are necessary to evaluate the response of the vegetation on treatment with organic fertilizer in order to optimize productivity of the hayfield and sustain species richness.
\end{abstract}

Keywords: fertilizers, grasslands, floristic composition, biomass yield, Festuca rubra, Agrostis capillaris.

\section{Introduction}

Vlăhița locality is situated in Harghita Mountains, in the upper part of Homorodul Mic and Pârâul Vârghiş Rivers. It is the city with the highest altitude ( 860 meters above sea level) from Harghita County, Romania (Vofkori, 1998). According to the geological map (http://atlas.anpm.ro/atlas\#) the territory is characterized by volcanogenic-sedimentary formations, pyroclastic breccias, agglomerates, pyroclastic microbresches, microconglomerates and tuffs alternating with conglomerates, microconglomerates, sandstones, and sands of andesitic nature. In the area haplic luvisols and albic luvisols (World Reference Base for Soil Resources, WRB-SR-1998) are dominating, that correspond to luvosol according to the Romanian Soil Taxonomy System (Florea and Munteanu, 2012). The average annual temperature is $4-6{ }^{\circ} \mathrm{C}$, while the average annual rainfall is $1000-1200 \mathrm{~mm}$ (Burus, 2007). The 
herbaceous vegetation is represented by various associations dominated mostly by Agrostis capillaris, Festuca rubra, and Nardus stricta (Csürös, 1963).

The grasslands from Vlăhița locality are commonly used for mowing, thus fertilizers are applied every second or third year.

The aim of the research was to examine the effect of different fertilizers on the floristic composition and biomass yield of the seminatural grassland used as hayfield near Vlăhița locality (Harghita County, Romania) in order to improve its management. In the same time the qualitative structure of the studied grassland was evaluated after the first application of the fertilizers.

\section{Materials and Methods}

The experiment was conducted in 2020 near Vlăhița locality $\left(46^{\circ} 20^{\prime} 44.85^{\prime \prime} \mathrm{N}\right.$; $\left.25^{\circ} 32^{\prime} 39.76 " \mathrm{E}\right)$ on a plane territory used as hayfield, at $857 \mathrm{~m}$ above sea level. In the hayfield, five experimental plots were delimited, with $10 \mathrm{~m}$ distance between them. The size of one plot was of $225 \mathrm{~m}^{2}(22.5 \mathrm{~m}$ long and $10 \mathrm{~m}$ wide). In each plot different type of fertilizer was applied. One plot was kept as control. The utilized fertilizers and the doses were: NPK 12:12:17, $150 \mathrm{~kg} / \mathrm{ha}+\mathrm{NH}_{4} \mathrm{NO}_{3} 150$ $\mathrm{kg} / \mathrm{ha}$ (chemical fertilizer), diluted cattle manure $50 \mathrm{~m}^{3} /$ ha (diluted fertilizer type I), diluted cattle manure $100 \mathrm{~m}^{3} / \mathrm{ha}$ (diluted fertilizer type II), and cattle manure 20 t/ha (organic fertilizer). All fertilizers were applied on one occasion in spring (of the year 2020). In the previous years, on the studied territory, diluted manure from cattle was applied for one time every second year.

The identification of the studied association was made based on the BraunBlanquet method and the work Les associations vègètales de Roumanie Tome 2 Les associations anthropogènes (Coldea,
2012). The qualitative structure of the grassland was assessed before mowing (when grasses were in flowering stage), according to Cristea et. al (2004), but also the work of Păcurar and Rotar (2014) was used. The relevés size was $25 \mathrm{~m}^{2}$, and 2 relevés were effectuated in case of all experimental plots.

The produced biomass was estimated by sampling with mowing from 1 square meter surface. In case of all plots 4 biomass samples were taken. The obtained biomass was immediately weighed and expressed as biomass yield in $\mathrm{t} / \mathrm{ha}$. To compare biomass yields Oneway-ANOVA and Tukey's pairwise test of the software Past (version 4.03) were used.

\section{Results and discussions}

The studied association was included in the following phytocoeno-system (Coldea, 2012):

Cls. Molinio-Arrhenatheretea R. Tx. 1937

Ord. Arrhenatheretalia R. Tx. 1931

All. Cynosurion R. Tx. 1947

Ass. Festuco-Agrostetum capillaris Horv. 1951

All vegetation surveys were made at one time, before mowing, and a total of 84 plant taxa were identified: 38 taxa in the control plot, 50 taxa in the plot with chemical fertilizer, 48 taxa in the plot with diluted fertilizer type I, 44 taxa in the plot with diluted fertilizer type II, and 55 taxa in the plot with organic fertilizer. The diversity index (Shannon) was higher in the fertilized plots (2.575-chemical fertilizer, 2.642-diluted fertilizer type I, 2.752-diluted fertilizer type II, and 2.637-organic fertilizer) than in the control plot (1.825). This result is in accordance with other studies that report the increase in species richness by the utilization of organic fertilizer (Tong et al., 2019) or different type of fertilizers (mineral nitrogen or manure) (Samuil et al., 2013). However mineral fertilizers are responsible for long-term 
nitrogen deposition and can decrease biodiversity (Stevens et al. 2004; Pallett et al., 2016).

The characteristic and dominant species of the association were Agrostis capillaris and Festuca rubra. In the composition of the association many species from the Cynosurion alliance (Trifolium repens, Cynosurus cristatus, and Phleum pratense) and from the Arrhenatheretalia order were present (Achillea millefolium, Leucanthemum vulgare, Lotus corniculatus, Trifolium hybridum, Senecio jacobaea, Leontodon hispidus, Plantago media, Veronica chamaedrys, Knautia arvensis, Daucus carota, and Dactylis glomerata). Other species with high abundance-dominance values were: Deschampsia cespitosa, Holcus lanatus, Centaurea nigrescens, Anthoxanthum odoratum, and Carex hirta.

The spectrum of bioforms shows that hemicryptophytes $(\mathrm{H})$ are in high number (Fig. 1). The altitudinal index $\left(K_{a}=12.69\right)$ indicates that the vegetation has developed in a mountain area, with moderate climate, and moderate anthropogenic pressure (Cristea et. al 2004).

The spectrum of floristic elements shows that the Euro-Asian (Euras.) elements are in high number. The species number is high also for the European (Eur.), Circumpolar (Circ., cold climate species), and Cosmopolite (Cosm.) elements (Fig. 2).

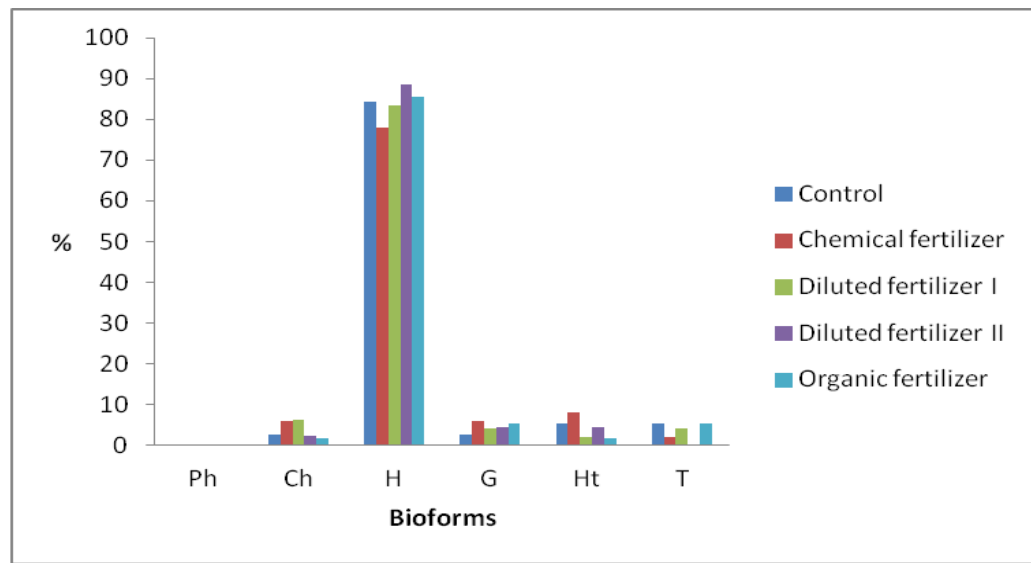

Fig. 1. The spectrum of bioforms in function of the applied fertilizer

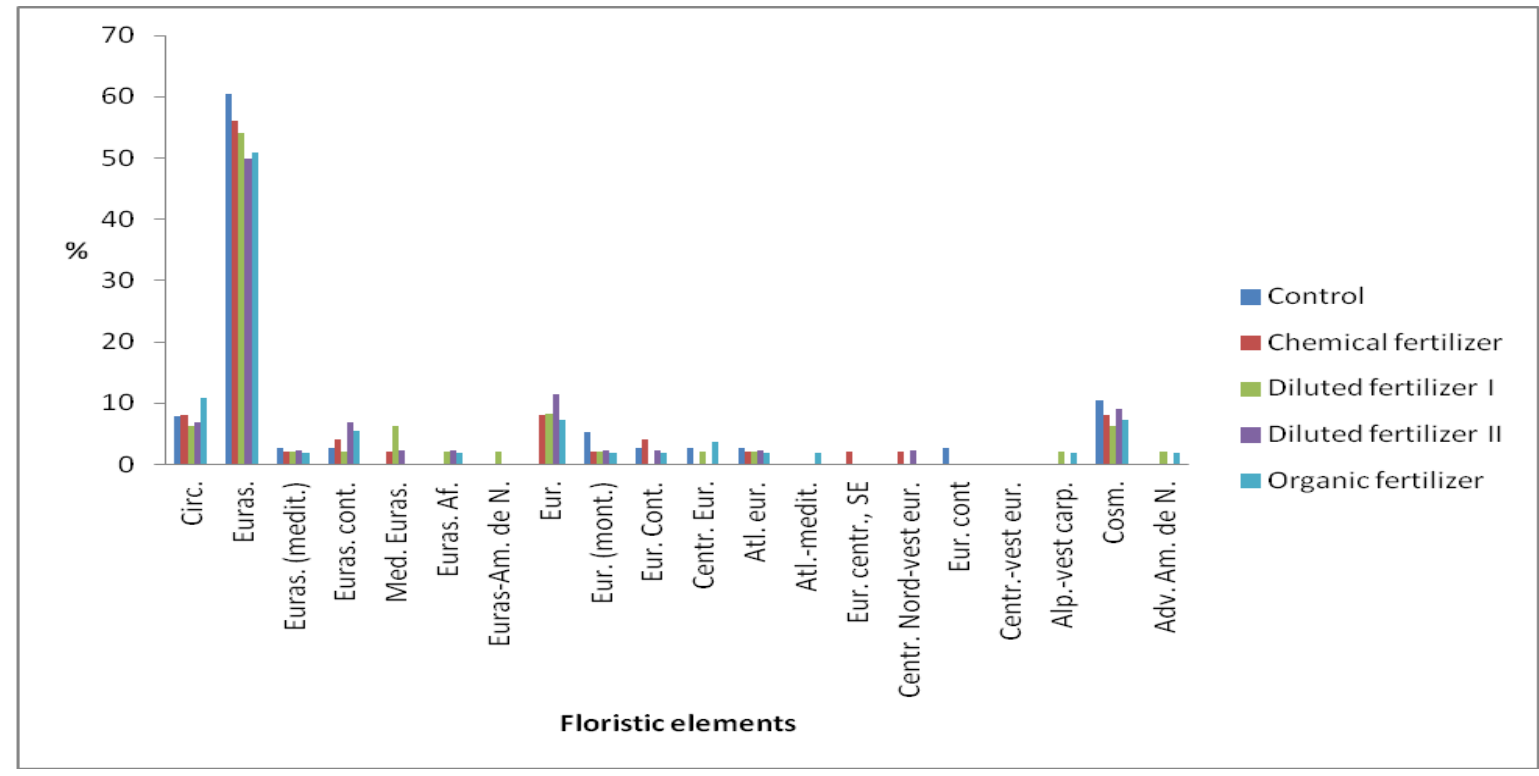

Fig. 2. The spectrum of floristic elements in function of the applied fertilizer 
In the association two adventitious species (Cuscuta campestris and Erigeron annus) were identified. One taxa listed in the Romanian Red List was found (Achillea ptarmica) (Oltean et al., 1994).

The spectrum of edaphic humidity, highlights the slightly $\left(\mathrm{U}_{4}\right)$ and moderately moist soil species $\left(\mathrm{U}_{5}\right)$, together with the welldrained soil species $\left(\mathrm{U}_{6}\right)$. The euryhydric species $\left(\mathrm{U}_{\mathrm{x}}\right)$ are also in high number. The plot with organic fertilizer had the highest number of wet soil species, while the plot with chemical fertilizer had the highest number of slightly and moderately moist soil species (Fig. 3).

In the spectrum of air temperature the euriterm species $\left(\mathrm{T}_{\mathrm{x}}\right)$ are in high number, followed by species of temperate zones, characteristic to the hilly $\left(\mathrm{T}_{6}\right)$ and submountainous floor ( $\mathrm{T}_{5}$ ) (Fig. 4).

In all plots the euryionic species $\left(\mathrm{R}_{\mathrm{x}}\right)$ were in high number, followed by the species of moderately and slightly acid soils $\left(\mathrm{R}_{5}, \mathrm{R}_{6}\right)$ (Fig. 5).

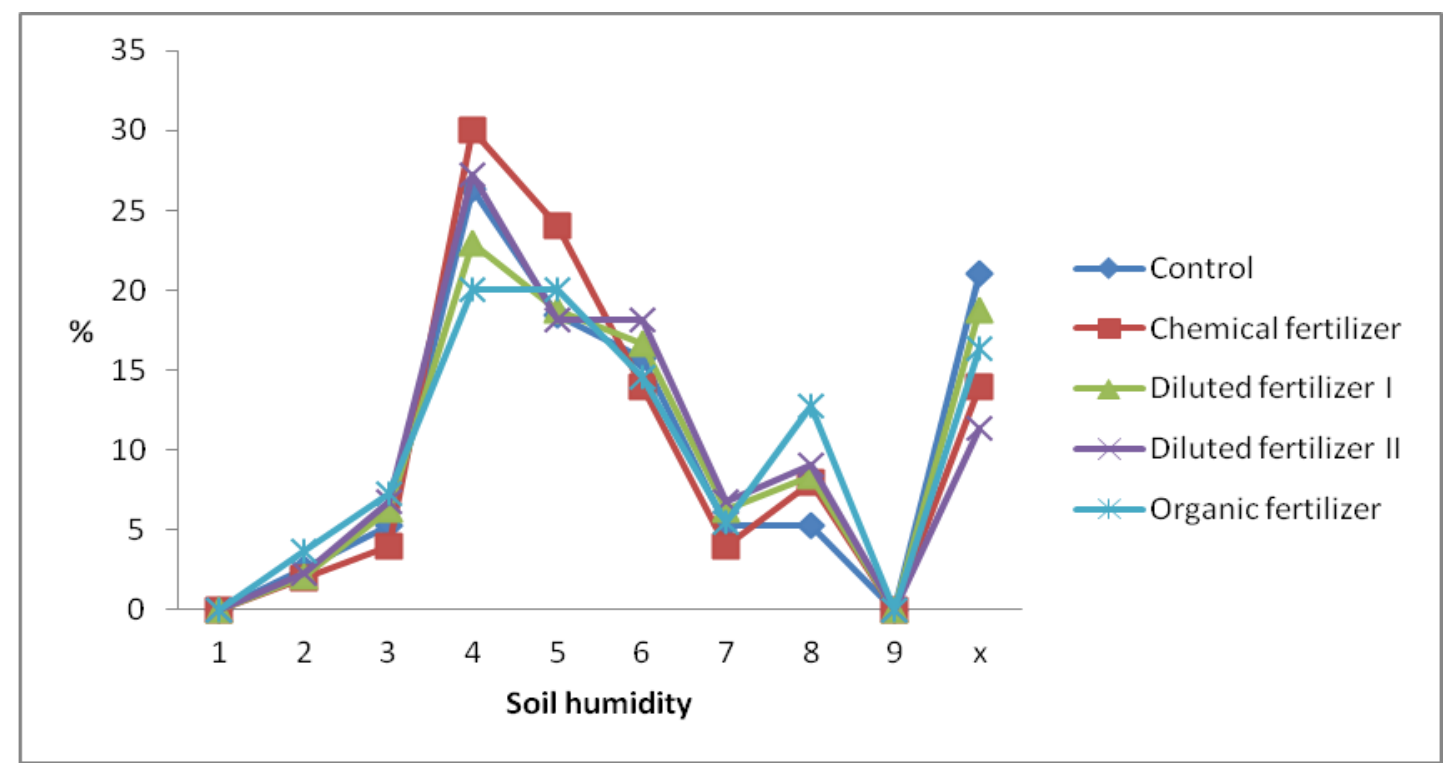

Fig. 3. The ecological spectrum for the edaphic humidity in function of the applied fertilizer

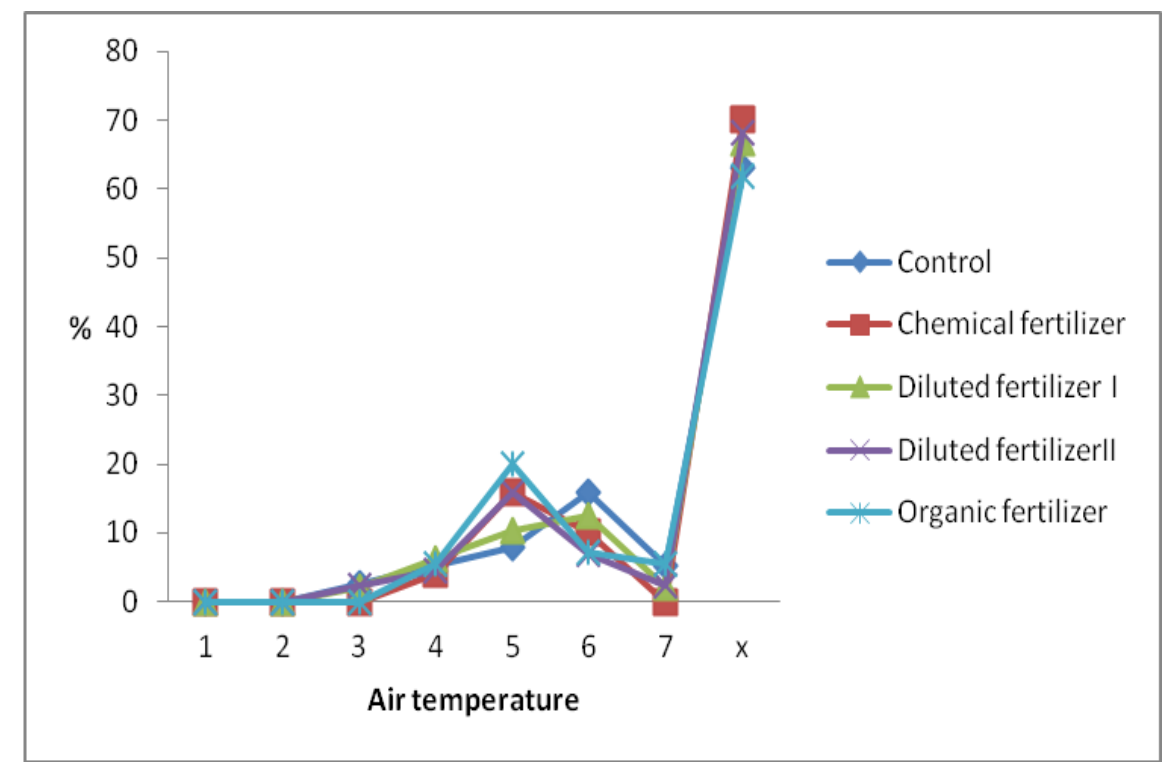

Fig. 4. The ecological spectrum for the air temperature in function of the applied fertilizer 
Regarding the spectrum for soil mineral nitrogen content, in all plots the eurinitrofil species $\left(\mathrm{N}_{\mathrm{x}}\right)$ were better represented, followed by the species spread on soil with moderate mineral nitrogen content $\left(\mathrm{N}_{5}\right)$. However in case of the organic fertilizer and diluted fertilizer type II, the species spread on soil with poor mineral nitrogen $\left(\mathrm{N}_{2}\right.$ and $\left.\mathrm{N}_{3}\right)$ were in higher number compared to the other treatments. According to the field observations in the studied plots the species spread on excessive nitrogen-rich soil indicating deposition and pollution were not present (Fig. 6).
The values of the diploid index (the ratio between diploid and polyploid species) varied between 0.44 and 0.58. In all plots the polyploid species were in higher number (Fig. 7).

The fodder plants from the studied Festuco-Agrostetum capillaris Horv. 1951 association were listed in Table 1, together with their nutritional values (Pop, 1982; Cristea 2004).

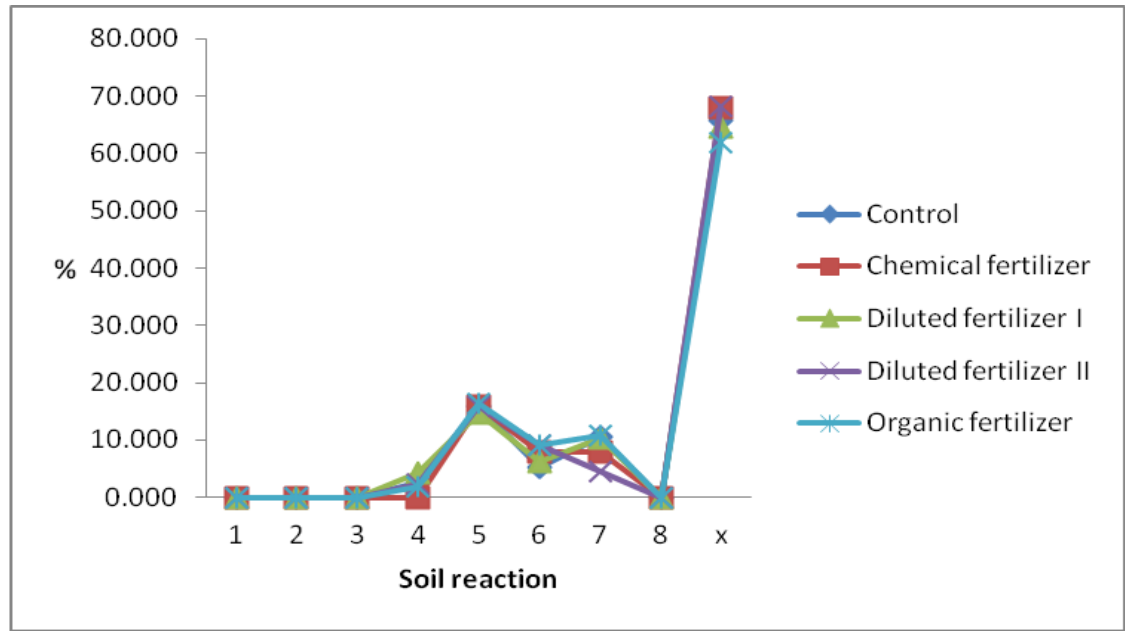

Fig. 5. The ecological spectrum for soil reaction in function of the applied fertilizer

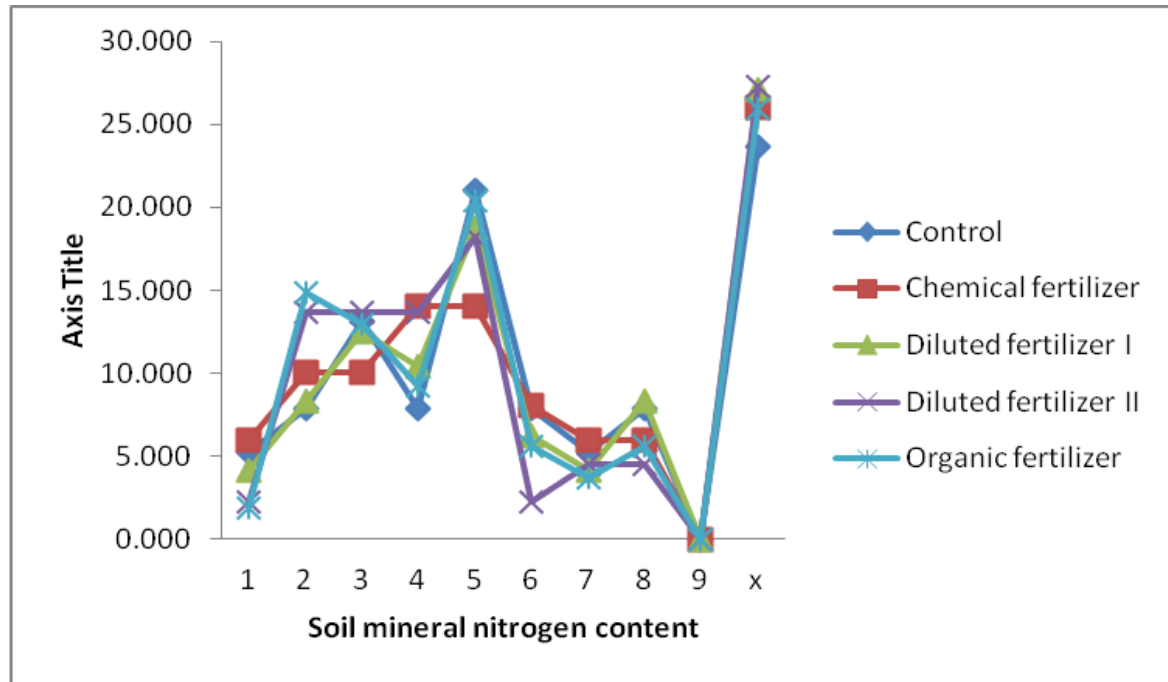

Fig. 6. The ecological spectrum for soil mineral nitrogen content in function of the applied fertilizer 


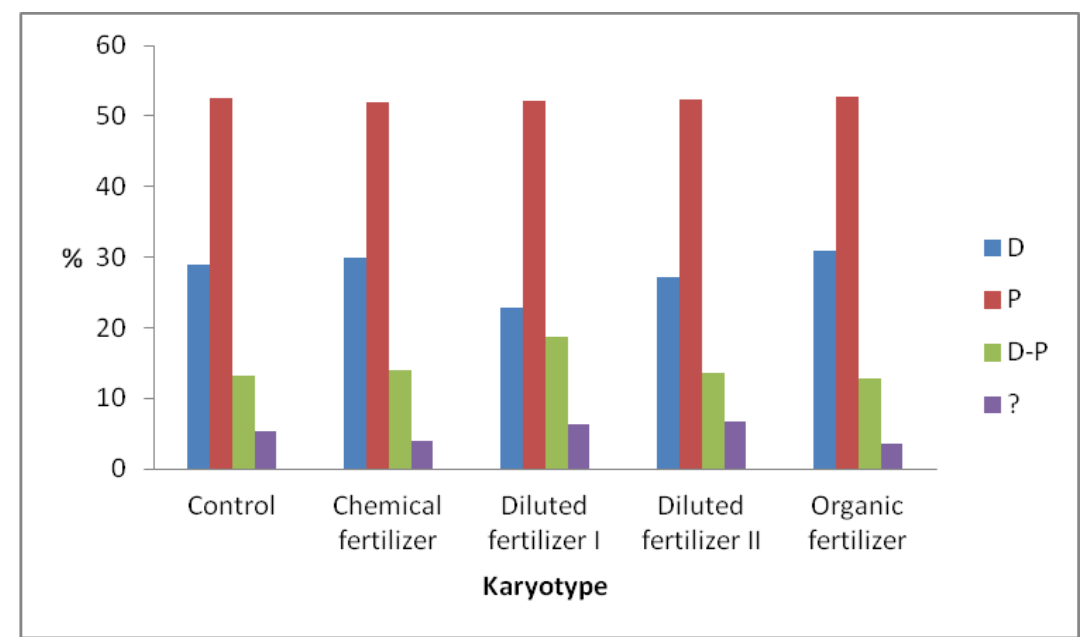

Fig. 7. The caryologic spectrum in function of the applied fertilizer

Table 1. Fodder plants identified in the Festuco-Agrostetum capillaris Horv. 1951 association near Vlăhița (Harghita County, Romania) and their nutritional values:

1-poor; 2- mediocre; 3-good; 4-very good (Pop, 1982; Cristea 2004)

\begin{tabular}{|l|l|l|l|}
\hline Species & $\begin{array}{l}\text { Nutritional } \\
\text { value }\end{array}$ & Species & $\begin{array}{l}\text { Nutritional } \\
\text { value }\end{array}$ \\
\hline Dactylis glomerata & 4 & Plantago lenceolata & 2 \\
\hline Festuca pratensis & 4 & Sanguisorba officinalis & 2 \\
\hline Phleum pratense & 4 & Trifolium montana & 2 \\
\hline Trifolium hybridum & 4 & Anthoxanthum odoratum & 1 \\
\hline Trifolium pratense & 4 & Carex hirta & 1 \\
\hline Trifolium repens & 4 & Chenopodium album & 1 \\
\hline Trisetum flavescens & 4 & Deschampsia cespitosa & 1 \\
\hline Agrostis capillaris & 3 & Holcus lanatus & 1 \\
\hline Cynosurus cristatus & 3 & Leontodon hispidus & 1 \\
\hline Festuca rubra & 3 & Plantago major & 1 \\
\hline Lotus corniculatus & 3 & Plantago media & 1 \\
\hline Taraxacum officinale & 3 & Potentilla erecta & 1 \\
\hline Alchemilla xanthochlora & 2 & Symphytum officinale & 1 \\
\hline Daucus carota & 2 & Tragopogon pratensis & 1 \\
\hline Elymus repens & 2 & Vicia cracca & 1 \\
\hline Phleum phleoides & 2 & & \\
\hline
\end{tabular}

The proportion of the main fodder plants (species from the Poaceae and Fabaceae family) was determined considering the abundance-dominance values of the species. In plots with diluted fertilizer type II and organic fertilizer a lower proportion of the family Poaceae and a higher proportion of other plant families (Fig. 8) could be observed. The differences in floristic composition could be partially explained by the differences found at the level of the abiotic factors. Most of the identified species from both plots indicated the poor mineral nitrogen content of the soil. In case of the plot with organic fertilizer a higher number of plants indicated the wet soil. In the plot with diluted fertilizer type II the species Carex hirta presented high abundancedominance values compared to the other studied plots.

Although plant diversity increased in all treated plots compared to the control, the coverage (abundance-dominance) of the species with good nutritional value decreased (Table 2). 


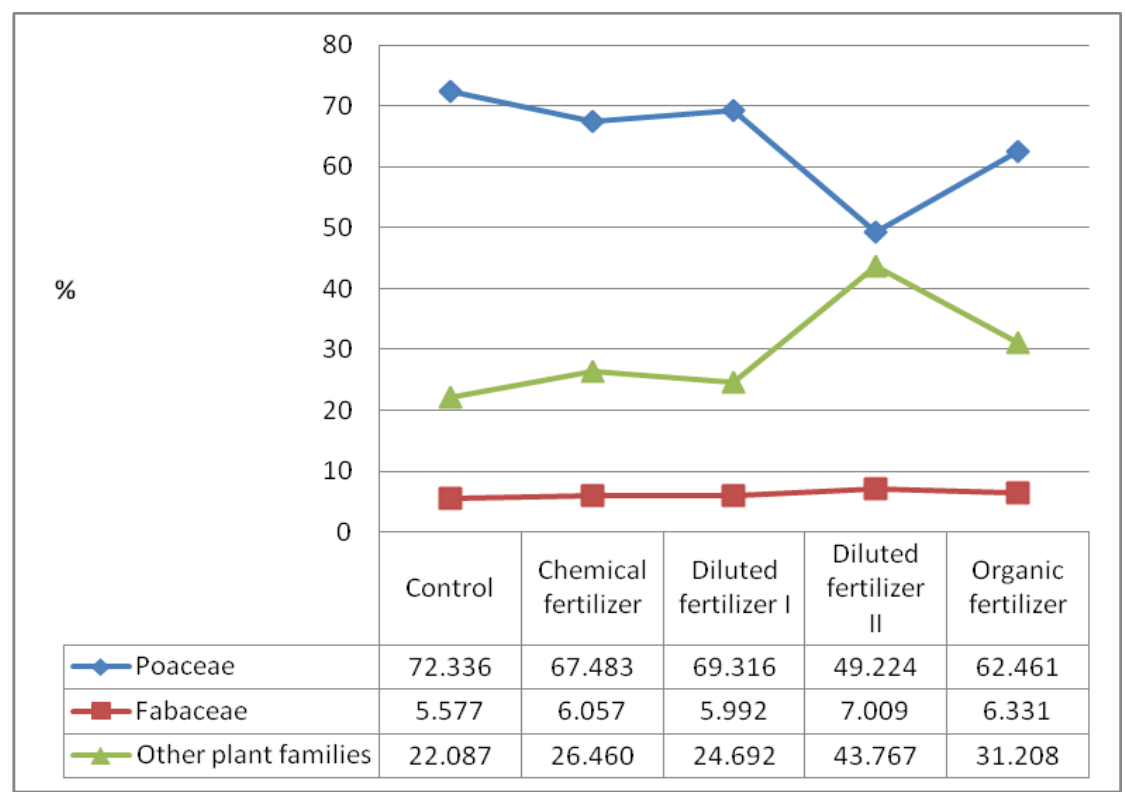

Fig. 8. The proportion (considering the abundance-dominance indices) of the main fodder species (Poaceae and Fabaceae) in function of the applied fertilizer

Table 2. The composition in economical categories: N-number of species; \%-proportion of the categories considering the abundance-dominance indices

\begin{tabular}{|c|c|c|c|c|c|c|c|c|c|c|c|}
\hline & \multicolumn{2}{|c|}{ Control } & \multicolumn{2}{|c|}{$\begin{array}{l}\text { Chemical } \\
\text { fertilizer }\end{array}$} & \multicolumn{2}{|c|}{$\begin{array}{l}\text { Diluted } \\
\text { fertilizer I }\end{array}$} & \multicolumn{2}{|c|}{$\begin{array}{l}\text { Diluted } \\
\text { fertilizer } \\
\text { II }\end{array}$} & \multicolumn{2}{|c|}{$\begin{array}{l}\text { Organic } \\
\text { fertilizer }\end{array}$} \\
\hline & & $\mathrm{N}$ & $\%$ & $\mathrm{~N}$ & $\%$ & $\mathrm{~N}$ & $\%$ & $\mathrm{~N}$ & $\%$ & $\mathrm{~N}$ & $\%$ \\
\hline \multirow[t]{4}{*}{ Fodder } & 1 & 8 & 2.56 & 9 & 20.61 & 6 & 26.45 & 8 & 31.06 & 8 & 30.98 \\
\hline & 2 & 5 & 2.42 & 5 & 3.90 & 6 & 7.52 & 5 & 6.06 & 7 & 9.56 \\
\hline & 3 & 4 & 57.37 & 4 & 29.11 & 4 & 23.16 & 5 & 18.08 & 5 & 7.75 \\
\hline & 4 & 5 & 7.11 & 5 & 6.07 & 6 & 7.82 & 2 & 4.73 & 6 & 4.46 \\
\hline \multirow[t]{3}{*}{ Melliferous } & 1 & 2 & 0.09 & 3 & 0.35 & 2 & 0.36 & 1 & 0.04 & 2 & 0.06 \\
\hline & 2 & 7 & 5.26 & 9 & 5.85 & 8 & 2.02 & 7 & 2.62 & 6 & 1.78 \\
\hline & 3 & 1 & 0.47 & 1 & 0.32 & 1 & 3.26 & 1 & 4.30 & 2 & 3.00 \\
\hline Toxic & & 11 & 16.20 & 12 & 15.76 & 11 & 15.31 & 10 & 12.03 & 14 & 8.43 \\
\hline Spiny & & 2 & 0.95 & 3 & 3.55 & 2 & 0.65 & 2 & 4.73 & 2 & 3.00 \\
\hline Medicinal & & 8 & 2.56 & 6 & 4.89 & 8 & 7.30 & 10 & 6.66 & 8 & 6.65 \\
\hline Industrial & Tc & 2 & 0.09 & 3 & 0.38 & 3 & 0.39 & 3 & 0.90 & 3 & 0.36 \\
\hline \multirow[t]{2}{*}{ Alimentary } & $\mathbf{C u}$ & 2 & 0.52 & 3 & 6.74 & 2 & 3.29 & 3 & 0.90 & 2 & 0.33 \\
\hline & Ol & 0 & 0 & 0 & 0 & 0 & 0 & 0 & 0 & 1 & 0.03 \\
\hline Decorative & & 1 & 0.47 & 2 & 0.35 & 2 & 0.65 & 3 & 0.52 & 3 & 0.62 \\
\hline Other plants & & 7 & 3.93 & 12 & 2.11 & 11 & 1.82 & 10 & 7.39 & 13 & 22.99 \\
\hline
\end{tabular}

Note-Fodder and melliferous plant categories: 1-poor, 2-mediocre, 3-good, 4-very good; Industrial plants: Tctinctorial; Alimentary plants: Cu-culinary, Ol-oleifer.

In a similar study with grassland edified by Agrostis capillaris and Festuca rubra it was found that manure improved mainly the growth of plants from other botanical families and no or less influence on the functional groups was observed. Manure had the highest positive effect on biodiversity by changing the soil nutrient composition and also by introducing 
new species that were present in the applied fertilizer (Samuil, 2013).

The biomass yield varied between 18.9 and 29.1 t/ha. All fertilized plots produced a significantly higher biomass yield compared to the control plot $(F=14.4, p<0.0005)$ (Fig. 9).

The positive effect of fertilizers on green biomass and floristic composition was observed after two years treatments in the Festuca rubra-Agrostis capillaris grassland from Băișoara (Cluj County, Romania). Application of manure (from cattle and horses) and/or mineral fertilizers increased the coverage of the Poaceae and Fabaceae family in the second and the third fertilization year (Rotar et al., 2016; Cirebea et al., 2020). Substantial increases in biomass yield in the following years after manure application were reported in many other grassland studies (Djukic et al., 2008; Štýbnarová, 2014; Botiș et al., 2015). Long-term studies (87-150 year) on the utilization of fertilizers demonstrated that chemical fertilizers reduce the soil $\mathrm{pH}$, increase soil organic carbon stock mainly in the soil fractions with coarse particle- and fine particle size, and have a negative effect on diversity and abundance of plants from the Fabaceae family and other forbs. Farmyard manure, instead increases soil organic carbon stock also in the very fine particle size soil fractions, prevents soil acidification, and has a positive effect on hey yield (Silvertown et al., 2006; Hejcman et al., 2014; Kidd et al., 2017).

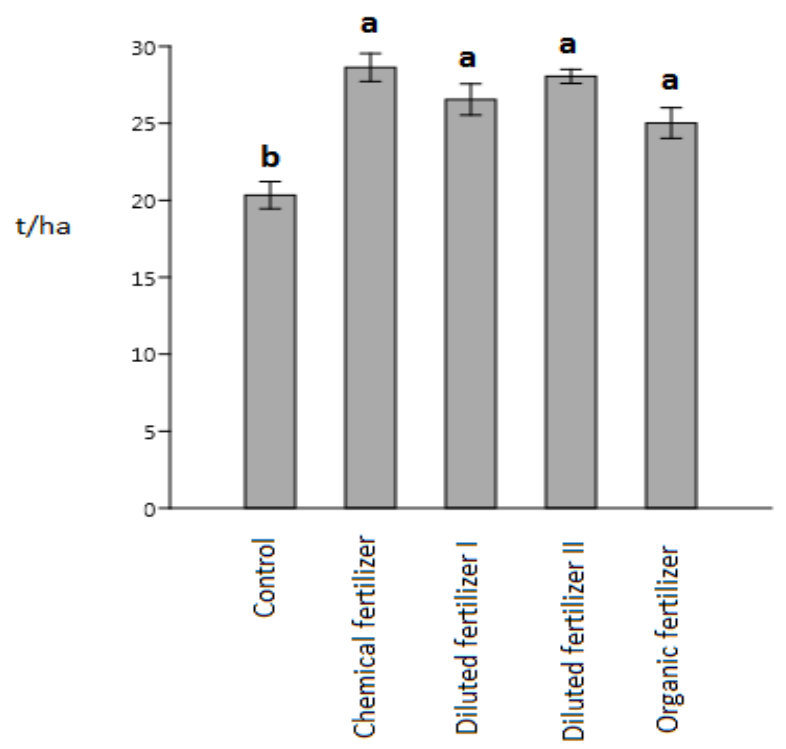

Fig. 9. Biomass yield ( $\mathrm{t} / \mathrm{ha}$ ) in function of the applied fertilizer (different letter indicate significant differences)

\section{Conclusions}

The studied semi-natural grassland presented a relatively high number of plant species, considering other similar associations. The qualitative structure analysis indicates that the vegetation has developed under moderate anthropogenic pressure. Beside the Euro-Asian elements the cold climate species (Circumpolar) and the Cosmopolite elements were well represented. Many species with high tolerance for temperature, soil $\mathrm{pH}$, and soil mineral nitrogen content were registered. No mineral nitrogen content deposition or 
pollution indicating species were found. After the first application of fertilizers in all treated plots the biodiversity increased compared to the control plot. Fertilized plots also had a significantly higher biomass yield than the control plot. Organic fertilizer reduced the proportion of the species with good nutritional value from the Poaceae family, but affected positively the proportion of other plant families than Poaceae and Fabaceae. Long-term experiments are necessary to evaluate the response of the vegetation on treatment with organic fertilizer in order to optimize productivity of the hayfield and sustain species richness.

\section{Conflict of Interest}

The authors declare that the research was conducted in the absence of any commercial or financial relationships that could be construed as a potential conflict of interest.

\section{Acknowledgments}

This work was supported by the Transylvanian Museum Society of Cluj-Napoca (BGA/8360/2019).

\section{References}

1. Vofkori L (1998) Székelyföld útikönyve III., Cartographia Kft., Budapest

2. Florea N, Munteanu I (2012) Sistemul român de taxonomie a solurilor (SRTS), Institutul Naţional de Cercetare-Dezvoltare pentru pedologie, agrochimie și protecția mediului - ICPA București

3. Burus T (2007) Szentegyháza és környéke idegenforgalmi lehetőségei, Magánkiadás

4. Csűrös Ş (1963) Scurtă caracterizare generală a vegetației din Transilvania. Acta Horti Bot București 2:825-853.

5. Coldea GH (ed.) (2012) Les associations végétales de Roumanie, Tome 2 Les associations anthropogènes Presa

Universitară Clujeană, Cluj-Napoca

6. Cristea V, Gafta D, Pedrotti F (2004) Fitosociologie, Ed. Presa Universitară Clujeană, Cluj-Napoca, 2004

7. Păcurar F, Rotar I (2014 ) Metode de studiu și interpretare a vegetaţiei pajiștilor, Ed. Risoprint, Cluj-Napoca

8. Tong Z, Quan G, Wan L, He F, Li X (2019) The effect of fertilizers on biomass and biodiversity on a semi-arid grassland of Northern China. Sustainability 11:2854. doi:10.3390/su11102854

9. Samuil C, Vintu V, Sirbu C, Stavarache M (2013) Influence of fertilizers on the biodiversity of semi-natural grassland in the Eastern Carpathians. Not Bot Horti Agrobo 41(1):195-200.

10. Stevens CJ, Dise NB, Owen MJ, Gowing DJ (2004) Impact of nitrogen deposition on the species richness of grasslands. Science 303. doi: 10.1126/science. 1094678

11. Pallett DW, Pescott OL, Schäfer SM (2016) Changes in plant species richness and productivity in response to decreased nitrogen inputs in grassland in southern England. Ecological Indicators 68:73-81.

12. Oltean M, Negrean G, Popescu A, Roma N, Dihoru G, Sanda V, Mihăilescu S (1994) Lista roșie a plantelor superioare din România - Studii, sinteze, documentații de ecologie, Ed. Acad. Română, București 1452.

13. Pop I (1982) Plante spontane și subspontane cu valoare economică din flora R. S. România. Contrib. Bot, 22:131-142.

14. Rotar I, Cirebea M, Păcurar F, Vidican R, Malinas A, Ranta O (2016) Mineral and organic fertilization influence on Festuca rubra-Agrostis capillaris natural meadow. Romanian Journal of Grassland and Forage Crops 13:39-46.

15. Cirebea M, Rotar I, Vidican R, Pleșa A, Morea A, Ranta O (2020) Impact of 
organo-mineral fertilization upon phytocoenosis and feed quality of the grasslands in the region of Transylvania. Romanian Agricultural Research 37

16. Djukic D, Stevovic V, Djurovic D, Ilic O (2008) The effect of organic fertilizer on biomass yield and quality of natural meadows. Options Méditerranéennes: Série A. Séminaires Méditerranéens 79:431-434.

17. Štýbnarová $M$, Mičová $P$, Fiala $K$, Karabcová H, Látal O, Pozdíšek J. (2014) Effect of organic fertilizers on botanical composition of grassland, herbage yield and quality. Agriculture (Polnnohospodárstvo) 60(3):87-97.

18. Botiş AL, Mihai GH, Sima N, Criste D, Mihalca I, Medrea I, Făgădar B (2015) Studies regarding the effect of organic fertilizers on a permanent grassland in Petrova, Maramureş. Bulletin UASVM Animal Science and Biotechnologies 72(2). doi:10.15835/buasvmen-asb:11420

19. Silvertown J, Poulton P, Johnston E, Edwards G, Heard M, Biss PM (2006) The Park Grass Experiment 1856-2006: its contribution to ecology. Journal of Ecology 94:801-814.

20. Hejcmana M, Sochorováa L, Pavlu V, Štrobach J, Diepolderc M, Schellberg J (2014) The Steinach Grassland Experiment: Soil chemical properties, sward height and plant species composition in three cut alluvial meadow after decades-long fertilizer application Agriculture. Ecosystems and Environment 184:76-87.

21. Kidd J, Manning P, Simkin J, Peacock S, Stockdale E (2017) Impacts of 120 years of fertilizer addition on a temperate grassland ecosystem. PLoS ONE 12(3): e0174632. https://doi.org/10.1371/journal.pone.01746 32 